\title{
Organizational Political Tactics in Universities
}

\author{
Bahareh Azizi Nejad (Corresponding \& First Author) \\ $\mathrm{Ph}$.D. Student of Educational Administration \\ Urmia University, Valfajre Ave, Urmia, Iran \\ E-mail: bahareh19@gmail.com \\ Mir Mohammad Seiied Abbaszadeh \\ Professor of Educational Administration \\ Urmia University, Valfajre Ave, Urmia, Iran \\ E-mail: m.abbaszadeh@urmia.ac.ir \\ Mohammad Hassani \\ Assistant Professor of Urmia University \\ Valfajre Ave, Urmia University, Postal Code: 57198-84375, Iran \\ E-mail: mhs_105@yahoo.com
}

Received: July 4, 2011

Accepted: July 11, $2011 \quad$ Published: December 1, 2011

doi:10.5539/hes.v1n2p65

URL: http://dx.doi.org/10.5539/hes.v1n2p65

\begin{abstract}
The present research aimed to promote understanding of political tactics in organizations. Political behavior in nowadays-complex conditions is a process that the conflicts, contrasts and differences among interested groups are resolved. It means dialogue, attention to different goals in organizations, regarding the interest of different groups, attraction of staff cooperation, and acquisition of the worker's support in management decisions, therefore technical and organizational wisdom are not sufficient. Managers along the development of organizations need to have political wisdom. In this study we surveyed political tactics perceptions of 1263 academic faculty members in West Azarbaijan State Universities. The research method was a descriptive-survey. Among these academic members, 376 individuals were chosen randomly as research sample. Questionnaire of 'political tactics' $(r=0.9)$ was used to collect data. The data were analyzed by using descriptive and inferential statistics as well as t-test, MANOVA, and Freidman test. Research findings showed that there were significant differences between academic degrees of the academic faculty members and political tactics used in the universities, whereas there was no any difference between gender of faculty members and political tactics. The survey revealed that the perceptions of political tactics among faculty members were different in West Azarbaijan State Universities; therefore, some practical suggestions are recommended.
\end{abstract}

Keywords: Organizational political tactics, Political behaviors, Dimensions of political tactics

\section{Introduction}

Globalization, technology advancement and desire of human beings to excel in the field have led to management of human behavior and channelizing it into correct direction has become important. Application of motivational theories, art of leadership and skill of redesigning jobs and modification of organizational structure is an ongoing process that facilitates positive work environment leading to raised job satisfaction of employees, greater productivity and organizational growth. Due to scientific knowledge development, managing human resources has become more challenging (Kondalkar, 2007). It has been observed that everybody wants to use power for influencing behavior of people in organization for gaining personal goals. So, in order to explain above- mentioned relationships, it is necessary to identify present political situation in organizations.

Politics in any organization is a nature of life. It has emerged as an important concept in organizational research, which receive considerable attention from industrial, and organizational psychologists and management scientists. This concept is studied with different perspectives in the organization (Sowmya, \& Panchanatham, 2011). Power is a 
fact of system at rest; politics is the study of power in action. An individual or subunit may have power within organizational content at some period of time; politics involve the actions of power to get something cultured as well as those activities which are undertaken to expand the power already possessed or the domain over which it can be exercised (Kondalkar, 2007). Dubrin (2001) defines organizational politics as informal approaches to earning power. Mayes and Allen (1977) state that organizational politics is the management of influence to obtain ends not sanctioned by the organization or to gain sanctioned ends through non-sanctioned influence means. Kacmar, Bozeman, Carlson and Anthony (1999) offered the following definition organizational politics includes actions by individuals, which are led toward the goal of furthering their own self-interests without regard for the well being of others or their organization. In this study we surveyed political tactics perceptions among academic faculty members in different state universities.

\section{Political Behavior}

The concept of political behavior in organizations has been a main research area for more than three decades. It has been addressed from a wide range of disciplines such as sociology, political science, psychology, human resources, and management. Each discipline has its own propositions and rules of evidence for studying political behavior in organizations. Yet they suggest that in today's business environment organizations are becoming more political entities. Three levels of political action are found in the organizations: Individual, coalition and network levels (Kinicki, 2008, p.158). There are multiple descriptions of political behavior in the literature. These set forth definitions of political behavior should not be considered as conflicting but complementing each other because each definition focuses on a different dimension of political behaviors in organizations. Furthermore, the word political behavior is interchangeable used with many other terms such as organizational politics, political process, political tactics, and company politics. Mintzberg (1983) defines organizational politics as personal or group behavior that is informal and typically schismatic. Gray and Ariss (1985) argue that the process of organizational politics is said to consist of intentional acts of influence undertaken by personals or groups to increase or protect their self-interest when conflict courses of action are possible. Drory and Romm (1988) define that political behavior is a power access and conflict, which hide motivation. Ferris et al. (1989) describe organizational politics as "a social influence process in which behavior is strategically designed to maximize short-term or long-term self interest, which is either consistent with or at the expense of others' interests. Dory and Romm (1990) argue that political behavior is informal influence behaviors meant to influence the distribution of organizational resources when there are conflict interests between individuals or group in the organization. They also suggest that political behaviors are the influencing behaviors, which encourage for pursuing individuals' or corporate goals and efforts of individuals, groups or organizations for influencing others (Ulkeryildiz, 2009). Valle and Perrewe (2000) argue that political behavior note tactical influence by social actors, which is specifically goal, oriented actions to raise self- interests, either in support of other social actors' objectives or hurts for others (Ulkeryildiz, 2009). Witt et al. (2000) notes organizational politics as phenomena in which organizational members try either directly or indirectly to influence other persons by means not sanctioned by formal standard operating manner or informal norms, in an attempt to earn personal or group purposes (Ulkeryildiz, 2009). Ferris et al. (2000) suggest that organizational politics involves an individual's appropriation to behaviors of self-serving intent, and can be defined as an individual's subjective evaluation about the extent to which the work environment is characterized by co-workers and supervisors who demonstrate such self-serving behavior. Vigoda (2003) suggests that political behavior refers the behavior of a social actor seeking for influence other social actors for the aim of promoting certain purposes and interests in the organization. Doldor (2007) describes organizational politics as to the existence of multiple competing interests within the organization and the influence processes enacted to manage them. The mentioned backgrounds from above review of different aspects of political behavior show that political behavior is an important part of organizational life that should be studied by researchers. Rezayian (2007) expresses three attitudes of individuals related to politics. Summary of his explanations are in below table. There are multiple descriptions of political behavior in the literature. These set forth definitions of political behavior should not be considered as conflicting but complementing each other because each definition focuses on a different aspect of political behaviors in organizations. So, the word political behavior is interchangeable used with some other terms such as organizational politics, political process, political tactics, and company politics (Ulkeryildiz, 2009). Consequences of the research studies on political behavior indicate reverse results. Some research studies show that political behavior has dysfunctional results such as conflict, job dissatisfaction, and lower productivity (Sussman et al., 2002). Some other research studies report that political behavior can have functional results (Ferris et al., 2000). Thus gaining a balance between employees' self-interests and organizational interests is an important key matter facing managers of them (Ulkeryildiz, 2009). The necessary condition for successful management of political behavior is cognition of below items that they are included: The emersion reason of political behavior, common technique of political behavior and normative solutions for limiting the affects of political behavior. Our current research was studied based on the use 
of common technique of political behavior as previously reported (Moorhead and Griffin, 2008).

\section{Political Tactics}

The political tactics are subset of political behavior that is used by a social actor for influencing other social actors to earn self-interests. Political tactics used in organizations differ from influence tactics but they have close similarities. The research studies on political tactics follow an independent development path from research studies on influence tactics (Sussman et al., 2002). There are different kinds of political tactics in organization. Some tactics are legitimate; others are illegitimate. When the tactics are based on dishonesty, and misinformation, they are hard to justify on moral grounds. Although political tactics are a fact of organizational life, not all are viewed as legitimate (Hoy \& Miskel, 2008). All members of an organization can engage in organizational politics. In fact, it seems likely that, regardless of hierarchical position, everyone is a player in the game of politics. Thus, we turn to a set of political tactics that are commonly used by employees at all levels (Hoy \& Miskel, 2008). Hoy and Miskel (2008) propose that political tactics can be categorized into below groups and this research is done about political tactics that Hoy and Miskel (2008) identified them. They consist of these below tactics: Ingratiating, Networking, Information management, Impression management and Coalition building (Hoy \& Miskel, 2008). In this research two common political tactics are chosen for study. They are information management and coalition building:

\subsection{Information Management:}

It is a tactic used by individuals who want to control others or build their own status. Although having critical information is useful in itself, the techniques used to spread the information can enhance one's position in both the formal and informal organizations. Releasing information when it has full impact can promote self- interest and defeat the ambitions of others. The key to information management is first to get crucial information (networking) and then to use it skillfully, making things known to others in ways that increase their dependence and build your reputation as one who really knows what is happening. Teachers who have networks that garner them important information are typically major actors in the political life of the school, and their careful nurturing and managing of that knowledge usually enhances their roles as important players in the political games of the school (Hoy \& Miskel, 2008).

\subsection{Coalition Building:}

It is the process of individuals banding together to achieve common goals. Teachers often join forces to oppose a proposed policy, to resist a proposed change, or to initiate change. A change in the curriculum is often successful depending on which teacher coalitions support or oppose it. Individuals alone are much less effective at influencing than groups; and relatively powerless groups become stronger if they can act together in coalition. Those teachers who are effective at organizing internal coalitions are often the political power players in a school (Hoy \& Miskel, 2008).

\section{Research Literature Review}

Two distinct categories of political tactics argued by Zanzi and O’Neil (2001) are sanctioned political tactics and non-sanctioned political tactics. Sanctioned political tactics refers political tactics that social actors consider acceptable because they are part of organizations' norms. On the other hand non-sanctioned political tactics are the ones that social actors consider unacceptable and undesirable. Social actors secretly perform non-sanctioned political tactics. They offer that social actor use 24 political tactics. Subsequently they conducted factor analysis to classify the proposed political tactics. The results of the factor analysis suggest that a two-factor solution is most appropriate for classifying the proposed political tactics. The first factor includes six political tactics: Use of expertise, super-ordinate goals, image building, networking, persuasion, and coalition building. The second factor includes seven political tactics: Intimidation and innuendoes, using surrogates, blaming or attacking, manipulation, organizational placement, co-optation, and control of information. Zanzi et al. (2001) label the first item and second item as non-sanctioned political tactics and sanctioned political tactics, respectively. Sussman et al. (2002) review classification scheme proposed by Allen et al. (1979) and argue that one of the original eight political tactics considerably overlaps with another political tactic proposed in the classification scheme. Therefore they propose reducing the number of political tactics used by social actors from eight to seven. These seven political tactics proposed by Sussman et al. (2002) include (1) attacking or blaming others, (2) using information as a political tool, (3) creating and maintaining a favorable image, (4) developing a base of support, (5) ingratiation, (6) developing allies and forming power coalitions, and (7) creating obligations and reciprocity.m They report that first and second the most frequently used political tactics include ingratiation and developing power allies/forming power coalitions respectively. The least commonly used political tactic is using information as an instrument. They also conducted a factor analysis to classify political tactics. The results of the factor analysis show that seven political tactics can be classified into two categories: Self focused tactics and relationship focused tactics. First one includes attacking or 
blaming others, using information as a political tool, creating a favorable image. Second one includes developing a base of support, developing coalitions, creating obligations. The results of the factor analysis also report that ingratiation political tactic is a moderator for both political tactic categories and the most frequent of this political tactic can also be attributed to its moderator role. Sussman et al.'s (2002) study also provides two important additional insights on political tactics in organizations. First one is extension of Allen et al. (1979) findings that vertical fragmentation in an organization influences the choice of political tactics. They suggest that not vertical fragmentation but also horizontal fragmentation influence the choice of political tactics. The research findings provide strong empirical support their proposition. Second one is the introduction of communication channels to research agenda of the political tactics. Sussman et al.'s (2002) political tactics carried out by using communication channels. They suggest that the communication channels used to send politically related messages can be classified into four major categories: (1) face to face, (2) telephone, (3) email, (4) written. The research findings also provide empirical support to their proposition that communication channels influence the choice communication used in sending politically related messages. Vigoda (2000) in his research which called "Organizational politics, job attitudes, and work outcomes: Exploration and implications for the public sector", reported that perception of organizational politics was found to have a negative relationship with job attitudes (e.g., job satisfaction and organizational commitment), a positive relationship with intention to leave the organization (exit), and a stronger positive relationship with negligent behavior (neglect). Drory and Gadot (2010) conducted a research called "Organizational politics and human resource management: A typology and the Israeli experience". They provide a critical examination of the meaning of organizational politics (OP) for human resource management (HRM). They expressed that develop their discussion in three main sections. First, they describe the negative image of OP and suggest that it has some positive dimensions useful for understanding HRM. Based on previous writings they present a balanced and non-judgmental approach towards politics in HRM. They extend the discussion to suggest a specific typology and model that, in their view, better explains the meaning of OP for HRM than current definitions. The model includes aspects of positive/constructive HRM negative/destructive HRM, ineffective HRM, and virtual HRM. Finally, they examine the implications of the model in the context of the changing Israeli cultural environment. The results of Karppinen's research (2008) indicate that the respondents have perceived rather considerable level of politics at their organization. Furthermore, employees in the case organization have experienced some political behavior during their performance appraisals. The results also show that there is a correlation between the general political climate and perceived political considerations in performance appraisals. Ferris and Kacmar (1992) empirically tested the model of organizational politics proposed by Ferris, Russ and Fandt and refined analysis of consequences of politics perception. The study aimed to develop a global measure of organizational politics perception. They have used multiple regression analysis to test the four predictors of organizational politics perception, which were found as job autonomy, feedback and advancement opportunity. The outcomes business relations and contentment were influenced by OP perceptions, at the same time organizational, personal items influenced organizational politics, which in turn influences the organizational results such as business involvement as well as business satisfaction.

\section{Research Methods}

Data collection method used in this research is questionnaire survey. The pilot study was conducted to control reliability and clarity of the survey instrument. First part of the questionnaire includes information on demographics of participants. Second part of the questionnaire includes a series of questions regarding political tactics in universities and includes objective items with Likert type-scale by five spectrums. The sample is used to collect data on usage of political tactics among academic faculty members in West Azarbaijan State Universities. The content of statistical sample is 376 individuals and they collected by randomly. There are four kinds of universities in West Azarbaijan State Universities, which are called Azad, Public, Long-distance and industrial universities (Table 1). SPSS Corporation was used to conduct the statistical tests. It is a commercial statistical analysis package (statistical software for the social sciences). To test the questions, after checking normal distribution, the following of proportional parametric statistical tests were used: $t$ single group and MANOVA (multivariate analysis of variance) for testing independent random observations, being normal, and the distance scale are required to $t$ single group and Friedman test was used for describing the ranking of political tactics.

\section{Findings}

The research findings are presented in both descriptive and inferential statistical forms, which are presented below. First, the demographic data are summarized in Table 2. In order to analyze data by statistical tests, the following questions were introduced:

Question 1. What are political tactics in present condition? 
Two political tactics are commonly used from Hoy and Miskel statements. The average of every two tactics (4 and 5) are higher than 3 (hypothetical average). When we used a single-sample t test to compare on every two-tactics, the result was statistically significant $(\mathrm{p}<0.05)$ (Table 3$)$.

Question 2. Are there any differences between faculty members political tactics application level based on academic degree in universities?

Analysis of the data showed that the score of political tactics application was 3.1 to 3.19. It means all were higher than average (3). In order to generalize the results to the statistical population, MANOVA analysis was used. The significant level was less than critical value $(0.05)$. The analysis showed that significant differences between academic degrees of faculty members and political tactics in universities. Further results are shown in Table 3.

Question 3. Are there any differences between faculty members political tactics application level based on tenure in universities?

Analysis of data showed the significant level was less than critical value (0.05). Therefore, differences between tenure of faculty members and two above tactics in universities were at $(\mathrm{p}<0.04)$ level (Table 3).

Question 4. Are there any differences between faculty members' political tactics application level based on gender in universities?

Statistically significant levels were more than critical value $(0.05)$ and $\left(\right.$ eta $\left.^{2}=0.02\right)$, so $\mathrm{H}_{0}$ was adapted. Therefore, there was no any difference between gender of faculty members and mentioned tactics in the universities (Table 3).

Question 5. Are there any differences between faculty members' political tactics application level based on post of the administrators and faculty members in universities?

Analysis of data showed the significant level was less than critical value (0.05). Thus, there were significant differences between the post of the administrators and faculty members in the universities (Table 4).

Question 6. How much political tactics was used by the administrator according to the viewpoints of the academic faculty members?

Analysis of data showed that the score of political tactics application was 1.99 to 2.17. It means all of administrators who are studied, have been used all of the political tactics less than average (3). In order to generalize the means to the statistical population, $t$ one sample test was used. The analysis, $t_{o b}$ was -29.05 to -38.32 , which means $t_{o b}>t_{c r}$ and Alfa is $5 \%$. Thus, the differences are statistically significant (Table 4 ).

Question 7. What are the ranking of political tactics applications among academic faculty members?

The ranking of the political tactics are provided by Freidman's analysis of variances test. The ranking order of the political tactics includes: Information management with average of 3.22 is the first priority, and coalition building with average of 2.87 is the second one (Table 4).

\section{Discussion/Conclusion}

George Strauss (1964) observes that the political system is a mass of competing power groups, each seeking to influence organizational policy for its own interests, or at least, in terms of its own distorted image of the organization's interest. Successful politics requires organizational members to bargain, negotiate, jockey for position, and engage in a myriad of political games, strategies, and tactics to influence the goals and decisions of their organization (Hoy \& Miskel, 2008). On the other hand, political behaviors are not destroyed from organization. In this research, our goal was to study common political tactics explained by Hoy and Miskel (2008) among academic faculty members in universities. Research findings showed that there are significant differences between academic degrees of the academic faculty members and political tactics used in the universities. Also there are differences between tenure of faculty members and political tactics used in universities. There are significant differences between faculty members' political tactics application level based on the post of administrators and faculty members in the universities. It can be explained that political behaviors the same as other organizational aspects isn't simple process and it is different from one organization to another. If a person who works for a long time in the organization or take long time to learn some skills, there is a lower probability that he or she will behave politically, because if a person who got fired, he or she would lose a lot. In an organization, people who are more experienced and powerful know that how they should behave politically whereas people with less experience may not make a right decision about their success, but Dubrin (1988) explored the relationship between age and the choice of political tactics and hierarchy level of social actor and his/her choice for political tactics. He reports that younger and lower-ranking social actors have stronger pre potency to use political tactics. It should be noted; political activities are achieved highly from organizational characteristics than individual differences (Rezayian, 2007). Therefore there is no any difference between gender of faculty members and above tactics in universities. These results are the same as 
findings of Allen et al. (1979). The research findings of Allen et al. (1979) suggest that the choice of political tactics tends to change with respect to social actor's hierarchy and a social actor's choice of political tactics depends on various individual characteristics of the participant. The ranking of political tactics are shown as information management and coalition building, respectively. Allen et al. (1979) was listed eight tactics in the following rating: Blame or attacking others, information management, impression management, creating supportive base for own, ingratiating, coalition building, socialized with influential people, established ethical norms. Applebaum, and Hughes (1998), Sussman et al. (2002), Zanzi and O'Neill (2001) studied about kinds of political tactics and their rankings. But their rankings were different from this research's ranking. Political behavior is inherently adaptive behavior. This is so for a simple and intuitive reason for people learning. People learn all kinds of things: to read, to speak, and to walk. They also learn concepts and form memories of their past actions. Most importantly, people use what they learn to make decisions, so that as they learn they can make better or at least different decisions. For example, if a person tries a new route to work and it takes less time, he/she learns and makes a different decision: $\mathrm{He} / \mathrm{she}$ takes the new route. People learn about politics as well, and what they learn affects whether they vote, whom they vote for and what they believe about politics and public policies. This matter indicates that political tactics are different in organizations. Therefore results of this research and other mentioned researches normally should be different (Collins, 2008). Finally if managers or principals expect that staffs and faculty members don't behave politically in a university or totally in an organization, they might have naive attitude because of their lack of political behavior however, political behavior should be controlled in order to be logical and desirable form.

Along with these findings, the practical suggestions can be argued to achieve reasonable usage of the political tactics as follows:

1) Creating an open management system. Disregarding persons who are too political when they are considered for employment.

2) Achieving a balance between the employees' self-interests and organizational- interests in the organizations.

3) Increasing political awareness of managers to identify their employees' political tactics, so that they could control their employees' behaviors.

4) Establishing formal process to discuss complaints and solve conflicts.

\section{Acknowledgment}

We wish to thank Dr. Mahmoud Djavani from University of Maryland for his ongoing support and proofreading of this paper and also all academic faculty members of West Azarbaijan State Universities for their cooperation.

\section{References}

Allen, R. W., Madison, D. L., Porter, L. W., Renwick, P. A., \& Mayes, B. T. (1979). Organizational politics: Tactics and characteristics of its actors'. California Management Review, 22, 77-83

Applebaum, S. H., \& Hughes, B. (1998). Ingratiation as a political tactic: Effects within the organization. Management Decision, 36, 85-95. http://dx.doi.org/10.1108/00251749810204160

Buchanan, D., \& Badham, R. (2008). Power, politics and organizational change: winning the turf game. London: Sage Publications.

Collins, N. A. (2008). Adaptive models of political behavior. Stanford University: A dissertation for the degree of doctoral philosophy. ProQuest LLC.

Doldor, E. (2007). Conceptualizing and investigating organizational politics: A systematic review of the literature. M.S. thesis; Cranfield: Cranfield University.

Dubrin, A. (1988). Career maturity, organizational rank, and political behavior tendencies: A correlation analysis of organizational politics and career experience. Psychological Reports, 63(2), 531-537

Ferris, G. R., Perrewe, P. L., Anthony, W. P., \& Gilmore, D. C. (2000). Political skill at work. Organizational Dynamics, 28, 25-37. http://dx.doi.org/10.1016/S0090-2616 (00) 00007-3

Ferris, G. R., \& Kacmar, K. M. (1992). Perceptions of organizational politics. Journal of Management, 18, 93-116. http://dx.doi.org/10.1177/014920639201800107

Greenberg, J., \& Baron, R. A. (1997). Behavior in organizations. Englewood cliffs. N.J.: Prentice Hall.

Hoy, W. K., \& Miskel, C. G. (2008). Educational administration: Theory research and practice. Publication: McGraw-Hill Companies.

Kondalkar, V. G. (2007). Organizational behavior. Publisher: New Age International. 
Karppinen, Virpi. (2008). The role of organizational politics in performance appraisal process. Helsinki University of Technology. BIT Research Centre, Laboratory of Work Psychology and Leadership.

Kinicki, Angelo. (2008). Organizational behavior core concepts. Publisher: McGraw-Hill.

Moorhead, G., \& Griffin, R. W. (2008). Organizational behavior. Translated by Mehdi Alvani \& Golamreza memarzadeh. Tehran: Golshan.

Overton, K., \& Frolick, M. N. (1996). The IS Machiavelli. Journal of Information Technology Management, 7, 23-33

Rezayian, A. (2007). Management of the political behavior in organization. Tehran: Samt.

Sussman, L., Adams, A. J., Kuzmits, F. E., \& Raho, L. E. (2002). Organizational politics: Tactics, channels, and hierarchical roles. Journal of Business Ethics, 40, 313-329. http://dx.doi.org/10.1023/A:1020807700478

Sowmya, K. R., \& Panchanatham, N. (2011). Job burnout: An outcome of organizational politics in banking sector. Far East Journal of Psychology and Business. 2 (1).

Ulkeryildiz, R. E. (2009). Political tactics in building construction industry from the architects' perspective. Izmir institute of technology: A thesis submitted to the graduate school of engineering and Science.

Valle, M., \& Perrewe, P. L. (2000). Do politics perceptions relate to political behaviors? Tests of an implicit assumption and expanded model. Human Relations, 53(3), 359-386. http://dx.doi.org/10.1177/0018726700533004

Vigoda, E. (2003). Developments in organizational politics. Cheltenham: MPG Books Ltd.

Vigoda, E. (2000). Organizational politics, job attitudes, and work outcomes: exploration and implications for the public sector. Journal of vocational behavior, 57, 326-347. http://dx.doi.org/10.1177/0018726700533004

Witt, L. A., Kacmar, K. M., Carson, D. S., \& Zivnuska, S. (2002). Interactive effects of personality and organizational politics on contextual performance. Journal of Organizational Behavior, 23(8), 911-921. http://dx.doi.org/10.1002/job.172

Zanzi, A., \& O’Neill, R. M. (2001). Sanctioned versus non-sanctioned political tactics. Journal of Managerial Issues, $13,245-262$

\section{Appendix}

Table 1. Number of statistical population.

\begin{tabular}{|c|c|}
\hline No of Faculty* & List of Universities \\
\hline 729 & Azad university \\
\hline 374 & Public university \\
\hline 113 & Long-distance university \\
\hline 47 & Industrial university \\
\hline 1263 & Total \\
\hline
\end{tabular}

* Individuals were chosen randomly as research sample. 
Table 2. Demographic data of statistical sample.

\begin{tabular}{|c|c|c|c|}
\hline Percentage & Frequency & Studied Variables & Demographic Items \\
\hline 52.12 & 196 & Instructor & \multirow{4}{*}{ Academic Degree } \\
\hline 38.03 & 143 & Assistant Professor & \\
\hline 7.18 & 27 & Associate Professor & \\
\hline 2.65 & 10 & Full Professor & \\
\hline 35.63 & 134 & $1-10$ & \multirow{3}{*}{ Tenure } \\
\hline 47.60 & 179 & $11-20$ & \\
\hline 16.75 & 63 & More than 21 & \\
\hline 28.72 & 108 & Female & \multirow[t]{2}{*}{ Gender } \\
\hline 71.27 & 268 & Male & \\
\hline 21.54 & 81 & Administrator & \multirow{2}{*}{ Post } \\
\hline 78.45 & 295 & Academic faculty members & \\
\hline 100 & 376 & & Total \\
\hline
\end{tabular}

